\title{
Download
}

UDC 911.9:502 https://doi.org/10.17721/2308-135X.2021.64.53-60

Andriichuk Tamara Viacheslavivna, PhD Zhytomyr Ivan Franko State University, Zhytomyr, Ukraine

e-mail: andriychuk2012@ukr.net

Khomiak Ivan Vladyslavovych, PhD, Associate Professor Zhytomyr Ivan Franko State University, Zhytomyr, Ukraine

Demchuk Nataliia Stanislavivna,

PhD Zhytomyr Ivan Franko State University, Zhytomyr, Ukraine

Vlasenko Ruslana Petrivna,

PhD, Associate Professor Zhytomyr Ivan Franko State University, Zhytomyr, Ukraine

Kostiuk Vitalii Stepanovych,

PhD Zhytomyr Ivan Franko State University, Zhytomyr, Ukraine 


\section{ECOLOGICAL AND EDUCATIONAL ROUTE OF THE SACRED SPRINGS OF THE SLOVECHANSKO-OVRUCHSKY RIDGE}

The aim. The aim of the study is to exploring the possibilities of using the development of networks of ecological routes and the involvement of communities in environmental activities, on the example of creating an ecological and educational route in the Slovenian-Ovruch ridge.

Research methods. We apply standard field and cameral geobotanical and cartographic methods. Our field research lasted from 2004 to 2019. We have created many standard geobotanical descriptions and created several ecological-coenotic profiles using expeditionary and stationary field methods. We created landscape maps and laid a holistic system of ecological trails through its most famous natural sources using cartographic modeling methods. We have studied archaeological, historical, ethnographic and bibliographic materials.

The results. We have developed an environmental education site about $100 \mathrm{~km}$ long, which combines 13 of the most famous natural springs. Each of these natural springs is a cult object, associated with a large number of myths and rituals that are still actively practiced. The Slovechansko-Ovruch ridge first of all impressed researchers with powerful natural springs that burst to the surface. Over the millennia of human history, a cult of worship has been formed in these places for natural spring. For the first time, we consider indigenous culture as a way to adapt to environmental conditions. Our activities aimed at studying, preserving and improving these sources will activate local communities to care for the environment, cultural and historical heritage. The ecological and educational route "Natural springs of the Slovechansko-Ovruch ridge" is a unique system that represents natural phenomena of world importance in combination with indigenous culture, which is the adaptation of communities to local natural conditions. Creation of NP "Slovechansko-Ovrutsky ridge" is the only comprehensive and systematic solution that will ensure sustainable development of communities while preserving the natural and historical and cultural identity. The local population, which has unique historical, cultural characteristics, is becoming increasingly vulnerable to global changes in the natural environment without these steps. The aboriginal population is economically and ideologically strongly integrated with natural complexes, so their loss will lead to the degradation and extinction of aboriginal culture.

Scientific innovation. For the first time, we consider indigenous culture as a way to adapt to environmental conditions. 
Practical significance. The best way to promote caring for the environment is to involve local communities in the study, development and protection of natural resources. This is especially true in the area of design and creation of a national nature park.

Key words: national nature park, ecological trail, territorial communities.

References

1. Andrejchuk V.M., Buchko Zh.I. (2000) The question of studying the aesthetic possibilities of landscapes for recreational purposes. Gheoghrafichna nauka i osvita v Ukrajini: zbirnyk naukovykh pracj. Kyiv: Fitosotsiotsentr, P. 21 (in Ukrainian).

2. Andrienko T.L., Popovich S.Yu., Pryadko Ye.I. (1984) Finds on the Slovechansko-Ovruch Upland (Ukrainian Polissya). Botanicheskiy zhurnal, vol. 69, no. 7, pp. 958-962 (in Russian).

3. Buchko Zh.I. (2001) Methodological Problems of Natural Reception of Landscapes. Naukovyj visnyk Chernivecjkogho universytetu. Serija: Gheoghrafija. Chernivtsi: ChNU, no. 104, pp. 61-66 (in Ukrainian).

4. Gharbar O.V., Maslovsjka O.S., Khom'jak I.V. (2019) Prospects for the creation of a bilateral biosphere reserve in Central Polissya. Stalyi rozvytok krainy v ramkakh Yevropeiskoi intehratsii: tezy Vseukrainskoi naukovo-praktychnoi konferentsii zdobuvachiv vyshchoi osvity i molodykh uchenykh. Zhytomyr: «Zhytomyrska politekhnika», p. 13 (in Ukrainian).

5. Zhyla S.M., Khomjak I.V. (2008) Prospects and problems of creating a transboundary biosphere reserve. Stvorennja transkordonnogho biosfernogho rezervatu ta ekologhichnoji merezhi v Polissi. K .: National Committee of Ukraine for the UNESCO program "Man and the Biosphere", pp. 153-169 (in Ukrainian). 
6. Segheda Serghij. (2001) Anthropological composition of the Ukrainian people: ethnogenetic aspect. Kyiv: Elena Teliga Publishing House, 256 p. (in Ukrainian).

7. Skryljnikova Ljudmyla. (2007) Polissya demonology and its nomination in the dialect of the village of Stari Velednyky [Ovruch district]. Etnolinghvistychni studiji. P. Hrytsenko, V. Konobrodska (Ed.), Zhytomyr: Polissya, pp. 177-184 (in Ukrainian).

8. Smyk Gh.K. (1965) Essays on the flora of the Ovruch-Slovenian ridge. Ukrainskiy botanicheskiy zhurnal, 22 (4), 63-67 (in Ukrainian).

9. Tutkovskyj P.A. (1923) Slovechansko-Ovruch ridge and the coast of the river Slovechna. Geological and geomorphological description. Kyiv: UAS Publishing House, 59 p. (in Ukrainian).

10. Khom'jak I. V. (2005) Use of researches of the Slovechansko-Ovruch ridge with the educational and methodical purpose: mater. conf. Uman: UDPI Publishing House, pp. 25-27 (in Ukrainian).

11. Khom'jak I.V. (2010) Classification and anthropogenic transformation of ecosystems of the Slovechansko-Ovruch ridge. Extended abstract of candidate's thesis. Kyiv (in Ukrainian).

12. Khom'jak I. V. (2011) Legends of Nora. Grandfather's circle. Zhytomyr: Ruta, 167 p (in Ukrainian).

13. Khom'jak I.V., Korostecjkyj V.O. (2011) Socioecology with the basics of environmental ethics: a guide for students of classical universities. Zhytomyr: Ruta, 268 p (in Ukrainian).

14. Khom'jak I.V. (2012) Legends of Nora. The road of Givenora. Zhytomyr: Absolute print, 148 p (in Ukrainian). 
15. Khom'jak I.V., Dunajevsjka O.F., Rjabceva N.O. (2017) About the unique ecological tourist route "Legends of Nora". Nauka. Molodj. Ekologhija-2017: materialy XIII Vseukrajinsjkoji naukovo-praktychnoji konferenciji studentiv, aspirantiv ta molodykh vchenykh. Zhytomyr, pp. 161-163 (in Ukrainian).

16. Khom'jak I.V. (2018) Features of anthropogenic impact on the natural dynamics of ecosystems of Ukrainian Polissya. Ekologhichni nauky, vol. 1(20), no. 2, pp. 69-73.

17. Shvecj K.S., Khom'jak I.V. (2016) Prospects for the development of green tourism in Ovruch district. Suchasni problemy ekologhiji: tezy Khll Vseukrajinsjkoji naukovoji on-line konferenciji studentiv, maghistriv ta aspirantiv z mizhnarodnoju uchastju. Zhytomyr: ZhSTU, p. 26 (in Ukrainian).

18. Shynkarenko U.Ju. (2020) On the need to create NPP "Slovechansko-Ovrutsky ridge" as a catalyst for the development of the Zhytomyr region. Naukovyj oghljad, vol. 6, no. 69, pp. 6-20 (in Ukrainian).

19. Leopold A. (1979) Some fundamentals of conservation in the southwest. Environmental ethics, vol. 1, pp. 131-141.

20. Leopold A. (1990) Means and ends in wildlife management. Environmental ethics, vol. 12, pp. 329-332.

21. Nash R. (1988) The rights of nature. A history of environmental ethics. Madison: The Univ. Wisconsin Press, $290 \mathrm{p}$. 